\title{
MOET ONS DIE SEDELIKE TOT 'N FUNKSIE BEPERK?
}

('n Diskussie na aanleiding van dr. J. A. L. Taljaard se Die mens, die liefde en die sedelike, Koers, Junie 1956.)

Met besonder belangstelling het ek hierdie geesdriftige en interessante bydrae van dr. Taljaard gelees. My diskussie beperk ek weens plaasruimte tot enkele hoofgedagtes, al sou ek graag op meer ingegaan het.

Taljaard se waarskuwing teen 'n versoening van of sintese tussen skriftuurlike en nie-skriftuurlike denke wil ek dubbel onderstreep. Dergelike sinkretisme het vir die Christelike denke onberekenbare verwarring en afdwaling beteken.

Dit is egter wetenskaplik gevaarlik om so sonder meer ooreenkomste tussen bv. en i.c. huidige Calvinistiese denkers en paganisties Griekse denkers aan dergelike sinkretisme toe te skrywe. Dan verval jy gemaklik in die drogrede van post hoc ergo propter hoc. Daar is immers ook ooreenkomste wat anders verklaar kan word. As bv. 'n Calvinistiese denker na selfstandige ondersoek en sonder beïnvloeding deur (miskien selfs sonder kennis van) betrokke Griekse denkers tot insigte kom wat met die van hulle punte van ooreenkoms vertoon, kan moeilik gesê word dat eersgenoemde laasgenoemdes navolg of by hulle aansluit. Die punte van ooreenkoms by die betrokke paganiste sou parsiële waarheidsmomente kon gewees het wat hulle kragtens die algemene openbaring van God kon ingesien het. Niemand tog sal beweer dat daar by die ou Griekse denkers geen enkele waarheidsmoment aanwesig is nie. Selfs wanneer 'n Griekse denker die oë van 'n huidige Calvinis vir 'n waarheidsmoment sou oopgemaak het, mag ons laasgenoemde nie dáárom veroordeel nie.

Maar die gevaar van verkeerde beïnvloeding bly - nie net deur denkers van die verlede nie maar ook deur denkers van die hede. Daarom geld vir elke Calvinis gedurig die eis van selfkritiek asook die spreuk: reformanda quia reformata.

Onder huidige Calvinistiese denkers (teoloë en wysgere) bestaan ' $n$ sewetal en miskien nog meer verskillende opvattings omtrent die sedelike. Aan die een kant mag dit onverkwiklik wees. Aan die ander kant mag dit iets bedenkliks wees as alle Calviniste in alle opsigte m.b.t. die vraagstuk van die sedelike ooreengestem het. Die laaste is die geval nieteenstaande hulle 
sowel uit die besondere as uit die algemene openbaring van God put. Want ons leef in 'n bedéling waarin die wetenskap histories al voortgaande gebou word, waarin verskeidenheid van aanleg en talente die een eerder dit en die ander eerder dát laat raaksien, waarin die mens en die skepping van God afgeval het en die rede van die mense verduister is, waarin die Calvinistiese denke nie hermeties afgesluit kan en mag word van die van andersdenkendes van die verlede en van die hede nie, en waarin meningsverskille ook wel tekens van wetenskaplike egtheid, aktualiteit en vrugbaarheid van die Calvinistiese denke mag wees.

Die betekenis van onderlinge meningsverskille mag ons nie onderskat nie. Dit is ons plig om deur selfkritiek asook onderlinge kritiek hulle te probeer oorwen. Ons moet mekaar se hande hou en mekaar probeer vind op die grondslag van wat ons gemeenskaplik is en alle antitetiese skoolvorming binne eie Calvinistiese kring moet ons bestry. Oorskatting van die betekenis van ons meningsverskille is ook verkeerd. As ons hulle besien op die agtergrond van die ryke skat van ons gemeenskaplike oortuigings en van ons gemeenskaplike instelling tot die wetenskap, dan tree hulle tot hul aangewese proporsies terug.

Afgesien daarvan wat ons presies bv. onder religie, godsdiens, geloof en die sedelike verstaan, moet daarop gelet word dat ons álgar, bv. die tien gebooie en die liefdesgebod van Christus aanvaar, verder aanvaar dat mense mekaar lief het en haat, dat hulle trou en/of ontrou aan mekaar is, ens., dat die sedelike deur die religie, resp. godsdiens (in gelowige of afvalsrigting) gelei en bepaal word, dat ons die sedelike ook nie kan en nie mag probeer isoleer van o.a. die juridiese, ekonomiese, ens. nie, maar dat desnieteenstaande die sedelike soeverein in eie kring is en ten slotte dat o.a. alle humanistiese en naturalistiese etiek bestry moet word.

Maar wat is die sedelike presies? Is die tien gebooie en die liefdesgebod van Christus 'n religieuse of 'n sedewet, is die tweede tafel en die tweede liefdesgebod 'n sedewet of nie, is die,wese', grond' of ,sinskern' van die sedelike in die wil met sy motiewe of in liefde in tydelike betrekkinge of in persoons- (self- en naaste-) liefde of nét in naasteliefde of nét in trou geleë? Hierop antwoord ons verskillend en vorm ons verskillende denkbeelde van die sedelike, omdat ons die sedelike op verskillende wyses benader en wel op grond van verskillende veronderstellings, verskillende probleemstellings en die gebruik van verskillende metodes.

M.b.t. meningsverskille omtrent die sedelike beperk ek my tot die opvatting van die sedelike deur Taljaard uiteengesit. 
Volgens Vollenhoven (by wie Taljaard hom hier aansluit) is die sedelike: trou in huwelik en vriendskap. Hiervolgens asook volgens die uiteensetting van Taljaard is die sedelike geleë in die horisontale rigting van mens tot mens. Trou in vertikale rigting van mens tot God moet dan religieus wees. Hiermee stem ek saam. In stryd hiermee vra Taljaard egter op bl. 312: „Of kan die mens ook in sy verhouding tot God ..... nie ook in 'n sedelike betrekking te staan kom nie?"'

Taljaard sien die eerste en die tweede liefdesgebod tesame as religieuse wet. Hier sluit hy hom by Dooyeweerd aan. Want Vollenhoven sien1) net die eerste liefdesgebod as religieuse wet. Maar nóg Dooyenweerd nóg Vollenhoven nóg Taljaard sien die tweede liefdesgebod as sedewet. Dooyeweerd in onderskeid van Vollenhoven en Taljaard sien die sedelike as ,love as a modal temporal refraction of the central ..... religious..... commandment of love".2) In hierdie verband wil ek net daarop wys dat by Vollenhoven die sedelike as ,trou in huwelik en vriendskap' horisontaal gerig is, nes die tweede liefdesgebod, en beide dus parallel is.

Hierteenoor sien ek die sedelike as persoons- (self- en naaste-) liefde en die tweede liefdesgebod van Christus as sedewet.

My eerste vraag aan Taljaard is: bestaan daar soiets as trou aan jouself, aan die beeld van God in jou, aan jou as volledige mens met die deur God aan jou en juis aan jou gegewe persoonlike roeping, self-trou gelei en bepaal deur liefde van jou tot God en gedra deur die liefde van God tot jou?3) Kan die mens ontrou aan homself, aan die beeld van God in hom en aan sy van God gegewe rocping wees? Is dit iets sedeliks resp. onsedeliks of nie? Indicn nie, waarom nie?

My volgende vraag aan Taljaard is: is bv. trou van ouers aan kinders, trou aan jou volk met sy van God gegewe roeping in sy volle betrokkenheid op God, trou van onderwyser aan leerling, trou tussen werkgewer en werknemer, ens. ens. nie ook iets sedeliks nie? Want het nie alle samelewingskringe aan ál veertien (resp. vyftien4)) wetskringe, en dus ook aan die sedelike as sodanig, deel nie, al het die samelewingskringe verskillende bestemmings- en funderingsfunksies? Taljaard gee dit op bl. 315 toe: „, Die sedelike funksie speel ook ' $n$ rol in alle ander menslike verbande en verhoudings". Daarom moet ek my tweede vraag anders formuleer: waarom is die sedelike dan nét trou in huwelik en vriendskap' en nie ,trou van mens tot mens in álle samelewingskringe' nie? Of is álle trou (behalwe huwelikstrou) vriendskapstrou? Taljaard heg egter tereg 'n besondere, innige en enge betektni aan vriendskap op bl. 315: „Twee mense wat nie tot die dood aan mekaar getrou is nie, kan nie vriende wees nie". Maar wat is dan tróu in daardie 
samelewingskringe wat nie huwelik en vriendskap is nie? Ook by hulle is dit trou tussen ménse hoe ook al hier tussen trou én trou (o.a. in ooreenstemming met die betrokke strukture van die samelewingskringe) onderskei mag word.

My twee vrae beoog die volgende: as Vollenhoven en Taljaard onder die sedelike álle trou tussen mense, m.a.w. self- en naaste-trous) wil versta an, dan het ons ver gevorder om mekaar te vind, want dan is ons opvatting van die sedelike denotatief dieselfde.

Maar mag ek dan mutatis mutandis aan Vollenhoven en Taljaard toevoeg wat hy op bl. 306 aan Geesinck en my toevoeg, nl. ,In die mens-totmens-verhouding lê dus vir die voorstanders van hierdie teorie die eg sedelike. Die paganiste by wie dus aansluiting gesoek en gevind word, is derhalwe diegene wat hierdie mens-tot-mens-verhouding 'n sedelike verhouding gemaak het"? Tog nie.6) O.a. nie omdat Geesinck en ek3) net soos hulle die sedelike nie los sien van religie resp. godsdiens en nie los sien van ons skriftuurlike opvatting van die verhouding van God, mens en wêreld nie.

Konnotatief verskil ons opvattings egter wel, want is die sedelike selfen naaste-liefde, of self- en naaste-trou? Waarom ek die sedelike as persoons(self- en naaste-) liefde sien, het ek in my Die grond van die sedelike uiteengesit. Hierby wil ek die volgende voeg. Persoonsliefde sluit trou in; trou is 'n inherente eienskapsbepaling van persoonsliefde as sodanig; waar persoonsliefde liefde tot die na die beeld van God geskape volle mens3 ) is (en dit sluit haat teen die sonde in álle mense in, asook dat die persoonsliefde deur die liefde tot God bepaal en gelei word), dáár is ook self- en naastetrou. Persoonsliefde is konkreet; dit is 'n akte wat o.a. gesindheid, diens, sorg (ook m.b.t. die gevolge van die sedelike handelinge) omvat en dit bevat óók funksionele bepalings, w.o. trou. Trou het sonder persoonsliefde geen sin nie en is op homself gestel (d.w.s. as funksie los van persoonsliefde gesien) abstrak. Aan die volheid van die sedelike laat persoonsliefde meer reg wedervaar as ,self- en naaste-trou', laat staan ,trou in huwelik en vriendskap'; en alle wetenskaplike resultate deur 'n analise van trou verkry, kom die analise van persoonsliefde ten goede omdat persoonsliefde trou insluit.

Waarom verskil ons opvatting van die sedelike konnotatief (en miskien ook denotatief)? Ons vorm verskillende denkbeelde van die sedelike want ons benader die sedelike met verskillende veronderstellings, probleemstellings en metodes-met die gevolg dat die Wysbegeerte van die Wetsidee a). die sedelike as 'n funksie en b). die religie resp. die religieuse wet as prefunksioneel 
en sentraal sien en c). met die denkbeeld van sentrum-funksie opereer.6a) Daarenteen onderskryf ek hierdie drie vooropgestelde bepalings nie.

As ek deur 'n denkbeeld vooraf geprejudiseer moes gewees het om die sedelike nét as 'n funksie te sien, dan sou ek met Vollenhoven en Taljaard die sedelike as trou opgevat het en nie soos Dooyeweerd die sedelike as ,love as .....temporal refraction....."2) gesien het nie. Want liefde (hoe ookal gesien) is geen funksie nie maar 'n akte, terwyl trou geen akte is nie, maar 'n funksie en i.c. 'n eienskapsfunksie en/of 'n funksionele verhouding tussen mense.6b)

Maar waarom moet religie as sentraal en die sedelike (asook die godsdienstige geloof, ens.) as funksies opgevat word? Met hierdie opmerking verwerp ek nie die modale (of wetskring-) onderskeidinge en ook nie dat in hulle funksionele bepalings gegee is nie, maar slegs die veronderstelling dat hulle algar as sodanig funksioneel is.

Ons tref in die Wysbegeerte van die Wetsidee verskillende lyne of denkbeelde aan w.o. die van Syn en sin, van Wetgewer en wet, van wet en ¡ubjek, van Archê en archimedespunt, van sondeval en verlossing, ens. Van al hierdie gryp ek net die skema of denkbeeld ,sentrum-funksie' aan smdat hierdie skematiese denkbeeld dié rede is waarom ons die sedelike rerskillend sien.

Maar ek moet versigtig wees. Ek glo nie dat my bedenkinge teen die srejudiserende invloed van die sentrum-funksie-denkbeeld so sonder meer Vollenhoven tref nie. Want al speel die terme ,funksie' en ,prefunksioneel' by hom 'n fundamentele rol, skyn die terme ,sentrum', ,sentraal' en ,konsentrasiepunt' in sy denke nie 'n (in elk geval nie daardie) beslissende rol te speel nie wat hulle by Dooyeweerd wel speel. Vollenhoven sien wel die hart (siel, gees) 9 ) as prefunksioneel en die liggaam as funksiemantel en die verhouding tussen beide as intra-individueel en die hart as rigtingsbepalend (na God toe of van God weg)(0) maar sover ek kon nagaan gebruik hy die terme ,sentraal' en ,sentrum' uiters selde en baie versigtig bv.: „Geest betekent in de Heilige Schrift richtingsprinciep. Vandaar dat dit woord in den zin van religieus centrum by schepselen gebruikt kan (ek kursiveer) worden zoowel voor aardsche als voor hemelsche (N.B.; H.G.S.) schepselen, die gericht zijn om God-al of niet gehoorzaam-de dienen."' ) By Dooyeweerd speel egter die denkbeeld sentrum-funksie 'n fundamenteel beslissende rol en Taljaard sluit hom hier by Dooyeweerd aan.

My bedenkinge teen die beslissende rol wat die sentrum-funksie-denkbeeld by Dooyeweerd speel, doen geen afbreuk aan my besondere hoë waardering wat ek vir sy (asook vir Vollenhoven se) skitterende en originele 
wysgerige prestasies koester nie; ek erken van harte dat ek onnoemlik veel van hierdie twee geniale denkers geleer het en ek werk nieteenstaande ons meningsverskille van harte met hulle saam.

Die humanisme gaan op een of ander wyse en wel in fundamentele sin van die mens uit en beskou alles, selfs God, vanuit hierdie gesigspunt as die mees fundamentele. Hierdeur word die mens of iets van hom implisiet en/of eksplisiet tot sentrum gestel. Alles draai om hom. By die Kantiaanse humanisme met sy gebruik van die transsendentale metode word die mens (met sy funksies) eksplisiet tot sentrum gestel, bv. as transsendentale eenheid van appersepsie, homo noumenon, transsendentale bewussyn of transsendentale subjek. Hier het ons die denkbeeld sentrum-funksie.12)

Dooyeweerd (wat in sy publikasies erken dat hy deur die Kantianisme heengegaan het voordat hy tot die Wysbegeerte van die Wetsidee gekom het) het met sy skitterende kritiek op die grensoorskrydende, verabsoluterende en antinomiese karakter van die (veral ook Kantiaanse) humanistiese wysbegeerte álle humanisme by die wortel afgesny. As ons nou van die Kantiaanse wysbegeerte sy grensoorskryding, verabsolutering en antinomië̈ wegdink, bly nog sy antroposentriese probleemstelling: ,begin by die mens' oor, asook sy eis van voorkeur vir die transsendentale metode; en daarmee die denkbeeld van sentrum-funksie.

Nieteenstaande sy kritiek op die (veral ook Kantiaanse) humanisme, aanvaar Dooyeweerd dieselfde probleemstelling en bevoorreg hy dieselfde (nl. transsendentale) metode en opereer sodoende ook met die denkbeeld van sentrum-funksie. Hy doen dit met die mede-gebruik van skriftuurlike veronderstellings; d.w.s. hy sien die probleemstelling en gebruik die transsendentale metode, in U lig'; m.a.w. sy denkbeeld van sentrum-funksie waarmee hy die wysgerige vraagstukke benader en die teorieë wat hy hiervolgens uitwerk is 'n Calvinistiese antwoord op 'n probleemstelling en metodegebruik wat ons ook by die Kantiaanse humanisme aantref.

Ter adstruasie hiervan die volgende. „, Know thyself' must indeed be written above the portals of philosophy.13) Philosophic thought as such derives its actuality from the ego. The latter restlessly seeks its origin in order to understand its own meaning14) and in its own meaning the meaning of our entire cosmos."15) Sy bevinding is vervolgens dat die hart van die mens as sentrum (resp. konsentrasiepunt van die individueel menslike bestaan) die filosofiese denke, die modaal funksionele verskeidenheid en die tyd transsendeer en dat die hart (in Christus gelowig,andersins afvallig) 
sentraal religieus bepaal is in sy gerigtheid op God al dan nie en dat Christus (in Wie ,the entire new humanity is one in root as members of one body"16)) na sy menslike natuur argimedespunt en konsentrasiepunt (sentrum) van die hele kosmos is. „The totality of meaning of our whole temporal cosmos is found in Christ with respect to his human nature".17) Ons het hier 'n antroposentriese, of beter:

'n Christo-antroposentriese opvatting van 'n deur God geskape en aan Sy wetsorde onderworpe kosmos. Let wel, die sentrum-funksie-denkbeeld is hier 'n kosmologiese17a) bepaling. Die een pool, nl. die sentrum is vir die menslike bestaan sy hart en vir die kosmiese totaliteit Christus na sy menslike natuur; die ander pool is die funksies soos in die wetskringleer uitgewerk.17b ) Van besonder belang is die beginsels van soevereiniteit in eie kring asook die van universaliteit in eie kring soos hulle geld vir elke wetskring. Die individualiteitstrukture omspan alle wetskringe en bind hulle in elke individuele geheel (stof, plant, dier en mens, huwelik, gesin, staat en kerk, ens.) op verskillende tipiese wyses saam. Die sentrum (sowel Christus na sy menslike natuur as die hart van die mens) transsendeer die verskeidenheid en tyd, maar alles, sentrum en funksies (en die hierin dimensioneel gefundeerde individualiteitstrukture), asook tyd, staan onder die wetsorde van God.

Hierdie denkbeeld van sentrum-funksie het 'n beslissende betekenis vir Dooyeweerd se leerstukke o.a. van die verhouding van die sentrum tot God (die Archê), die argimedespunt, die konsentrasiepunt, tyd, die botydsheid van die hart, religie, die dubbele liefdesgebod as één sentrale religieuse wet, die verhouding van ,Gegenstand' tot naiëwe ervaring en tot intuitiewe sintese die teologie as vakwetenskap (nes skeikunde 'n vakwetenskap is), die funksionele karakter van die modaliteite (waarvolgens o.a. godsdienstige geloof en die sedelike ook funksies is) en die liggaam as funksiemantel.

Teen hierdie kosmologies fundamentele sentrum-funksie-denkbeeld in die Wysbegeerte van die Wetsidee loop ek my telkens vas. Teen hierdie denkbeeld en sy deurwerking in al die betrokke leerstukke is my bedenking gerig en daarmee (wat ons probleem betref) teen die sentraliteit van die religie en die funksionaliteit o.a. van godsdienstige geloof en die sedelike, asook hul verhouding in die sentrum-funksie-relasie.

$\mathrm{U}$ moet my nie misverstaan nie. My bedenking is nie gerig teen die talryke (en waaronder baie originele) waarhede in hierdie leerstukke, en in die betrokke kritiek op onaanneemlike beskouinge nie, maar teen die 
intellektuele saambinding van dergelike waarhede in die knyp van 'n kosmologiese sentrum-funksie-denkbeeld.17c

Elke wysgeer (net soos elke ander wetenskaplike) opereer met denkbeelde, d.w.s. teoretiese konstruksies. Elke denkbeeld is ' $n$ vereenvoudiging van die nooit ten volle deursigbare ingewikkeldheid van die samehangende verskeidenheid aan ons geopenbaar. 'n Gerserveerde houding teenoor die eje denkbeeld is daarom ook 'n wetenskaplike eis. Dit beteken egter nie 'n gereserveerheid teenoor vasstaande waarhede met hierdie denkbeeld gegryp nie.

Wat enkele 18 ) bepalings betref van die denkbeeld waarmee ek werk die volgende.

M.i. is daar drie eenheidsbepalings van die aardse skepping of kosmos. Op die verhouding van hemel en aarde gaan ek nie in nie. Ek gee hulle in omgekeerde volgorde.

In die derde plek vorm die samehang van die radikale verskeidenheid (deur God in Sy skepping gelê) die intrinsieke (of as u wil ,immanente') eenheid van die kosmos.

In die tweede plek vind die kosmos in sy (en in die hiermee gegewe onderskeiding van die hele kosmos van God, m.a.w. in sy) kreatuurlikheid (w.o. sy onselfgenoegsaamheid, wetsgebondenheid, ens.) sy ekstrinsieke (of as u wil ,formele') eenheid.

In die eerste plek vind die kosmos m.b.t. sy radikale verskeidenheid, sy intrinsieke eenheid én sy ekstrinsieke eenheid sy transkosmiese eenheid in die skeppings- en bestieringswil van God Drie-ening, uit Wie, deur Wie en tot Wie álle dinge is. Hier mag ons die eenheid van die geskape heelal as 'n transkosmiese (of kosmies-transsendente) eenheidssentrum sien. Gód is Middelpunt. Die sentrum van die kosmos of skepping lê buite, transsendent aan, die kosmos.

Vir meer as hierdie drie eenheidsbepalings vind ek geen grond nie. Maar die Wysbegeerte van die Wetsidee wil 'n vierde eenheidsbepaling handhaaf, 'n binne-kosmiese of kosmies-immanente sentrum, 'n konsentrasiepunt van alle kosmiese verskeidenheid. Hiermee gaan ons denkbeelde uiteen.

Wat my betref: a). ek vind nêrens 'n grond vir die aanname van 'n konsentrasiepunt binne die skepping wat alle verskeidenheid en tyd transsendeer en die verskeidenheid as ' $t$ ware in ' $n$ knooppunt saamvat nie; b). die radikale verskeidenheid vind as sodanig sy oorsprong regstreeks in die 
skeppingswerksaamheid van God Drieënig; en c). deur nie 'n binne-kosmiese eenheidspunt te aanvaar nie staan ek ruimer as die Wysbegeerte van die Wetsidee in my benadering tot en die analises van die kosmiese verskeidenheid en van sy samehang en word ek o.a. nie vooraf geprejusideer om religie as sentraal, die liefdesgebod as sentrale wet en bv. die godsdienstige geloof asook die sedelike as funksies te sien nie, en is vir my die weg oop om o.a. die tweede liefdesgebod as sedewet op te vat, en die eerste liefdesgebod as die eerste en die grote (nie die sentrale nie) gebod vir die godsdienstige lewe.

Alhoewel Vollenhoven en Dooyeweerd in belangrike en fundamentele opsigte ooreenkom in hul opvattinge van religie (prefunksioneel), godsdienstige geloof (funksioneel) en die sedelike (funksioneel), verskil hulle ook. Vollenhoven sien religie in die eerste plek as ' $n$ verbond wat God met die mens opgerig het;19) hy sien nét die eerste liefdesgebod as religieuse wet; 1) hy sien hierdie gebod eintlik nie as sentraal nie,11) maar as die eerste en groot gebod; en hy sien die sedelike as trou.20) Dooyeweerd sien religie wysgerig as ,the innate impulse of human selfhood to direct itself toward the true or toward a pretended absolute Origin of all temporal diversity of meaning, which it finds focussed concentrically in itself"21) (waarby Dooyeweerd natuurlik die verbond tussen God en mens nie sal ontken nie); hy sien die hele (dubbele) liefdesgebod van Christus as' $n$ eenheid22) hy sien hierdie gebod in sy eenheid as die sentrale religieuse wet23) en hy sien die sedelike as ,love as temperal refraction" 2 ). Taljaard aanvaar die kursief gedrukte gedeeltes van hierdie beknopte saamvatting, en sluit hom dus, waar Vollenhoven en Dooyeweerd verskil, alternatief eers by die een en dan by die ander aan.

M.i. moet mens drieërlei verhouding van die skepsele tot God onderskei. Ons kan dit skematies met drie konsentriese sirkels voorstel. Die binnenste sirkel stel godsdiens in enger sin voor waarop die eerste liefdesgebod betrekking het en wat die verbond van God en mens veronderstel. Die tweede sirkel stel godsdiens in ruimer sin voor; ons noem dit religie. Dit het ook betrekking op die sedelike, die juridiese, ens., m.a.w. ook op die hele kulturele lewe van die mens, d.w.s. op sy vervulling van sy hele roeping op aarde. Die buitenste sirkel sluit ook die verhouding van stof, plant en dier tot God in; ons noem dit die teale. Want bv. 'n klip staan ook in 'n regstreekse verhouding tot God omdat dit 'n skepping van God is, sy voortbestaan van God afhanklik is, dit aan die wetsorde van God onderworpe is en ook die majesteit en krag van God openbaar. 
Godsdiens en religie kan ons nie skei nie, maar wel onderskei. Omdat die mens 'n eenheid is en die godsdiens die religieuse lewe lei en bepaal, het die verbond van God met die mens betrekking op sy hele religieuse lewe.

Tereg sê Vollenhoven dat die eerste liefdes gebod in sy vertikale gerigtheid die mens regstreeks in verhouding tot God stel, die tweede in sy horisontale gerigtheid nie.24, Maar as ons die tweede in sy verband met die eerste liefdesgebod neem, kan ons die menslike roepingsvervulling ook as 'n regstreekse verhouding tot God sien, maar dan bedoel ons met regstreeks iets anders. Ons het hier met twee saamhangende gebooie te doen en nie met een met 'n ,,indivisible unity"25) nie, want Christus spreek self van twee; verder die ,gelykheid" wat Hy tussen beide stel (Gr. hoos) laat dit twee bly26) en die woorde van Markus 12:31 „,Daar is geen ander gebod groter as diẻ nie" stel die kursief gedrukte, die' (Gr. toutoon) in die meervoud.

In my opvatting van godsdiens (in enger sien) is die geloof ' $n$ inherente ,bepaling' daarvan en hoef ek nie dit in twee ,dele” te onderskei nie, deur die een (nl. religie) as sentraal en prefunksioneel en die ander (nl. geloof) as funksioneel te sien nie, omdat ek nie met die denkbeeld sentrum-funksie opereer nie; en daarom hoef ek ook nie godsdienstige geloof bloot as 'n funksie te sien nie. Dieselfde geld mutatis mutandis vol van die sedelike.

Die sedelike is volgens die bogegewe uiteensetting religieus (godsdiens in ruimer sin). Omdat ek nie met die skema sentrum-funksie opereer nie, hoef ek die sedelike nie bloot as funksie te sien nie maar kan dit ook (ooreenkomstig die tweede liefdesgebod, resp. die sedewet) as persoons- (selfen naaste-) liefde27) sien en kan ek dit sien in sy samehang met en sy bepraldheid deur die eerste liefdesgebod.28) Bowendien kan ek ook alle ander kultuuraktiwiteite, as religieus sien.

Daar is nog baie wat ek in hierdie verband graag sou wil sê. Maar ek beperk my net nog tot die volgende. Die Wysbegeerte van die Wetsidee handhaaf tereg dat dit die besondere en eiesoortige eenheid van die mens (in sy verhouding tot God asook tot die orige skepping) skerp uitbring. Maar kan dit met behulp van 'n ander denkbeeld as die sentrum-funksiedenkbeeld nie ook gedoen word nie? Kan die Wysbegeerte van die Wetsidee aan die ander kant die eiesoortige cenheid van elk van dier, plant en stof tot sy reg laat kom? Is die eenheidsvraag van elk van mens, dier, plant en stof uiteindelik nie in misterie gehul nie? Maar dat die eenheid van die mens (geskape na die beeld van God en met sy hart as uitgange29) van die lewe) ' $n$ besondere is waarmee die eenheid van elk van dier, plant en stof onvergelykbaar is, spreek vanself. Die mens is egter kmings'kind 
en hoof van die skepping en Christus is Hoof en Koning van die mens en van die hele skepping. Hierby pas die kosmologiese sentrum-funksie-denkbeeld nie, altans nie vanself nie.

Die denkbeeld wat gevorm word hang saam met veronderstellings, probleemstellings en metodegebruik.

Dooyeweerd sê: ,Begin met die mens!'; , ,Know thyself!' must indeed be written above the portals of philosophy" 30 )

M.i. het die ,tempel' van die wysbegeerte drie ingangspoorte. Bo die sentrale en vernaamste staan: ,Ken God (as transkosmiese Middelpunt van die geskape heelal)!" Die twee gelykwaardige ingangspoorte weerskante van die sentrale dra respektiewelik die opskrifte: ,Ken die kosmos!' én ,Ken die mens (w.o. jouself en jou denke)!' Interessant is om in hierdie verband te let op die plekke wat God, wêreld en mens in Bavinck31) se wysbegeerte inneem.

Dooyeweerd sê: ,The transcendental critique of theoretical thought (d.w.s. die transsendentale metode) is, to be sure, the ultimate theoretical foundation of philosophy"32). Aan hierdie metode gee Dooyeweerd in fundamentele sin voorrang; dit is 'n metode wat, in a radical critical attitude......(fixes)..... our theoretical thought itself on its necessary presupposita, which are contained in the real structure of the first, more particularly, which are postulated by this structure" 33 ).

In ooreenstemming met die drie opskrifte bo die poorte van die wysbegeerte ken ek aan die fanerokritiese metode voorrang toe34). Dit is aan die openbaringsmetode van Bavinck en Hepp verwant. Hierdie metode rig sy oog nie op die voorwaardes van die teoretiese denke as sodanig nie, maar op dit wat (as sodanig) aan die denke gegee is om te ken.

Dooyeweerd se beslissings lei hom tot die denkbeeld van sentrumfunksie waarvolgens hy sy wysbegeerte bou. My beslissings lei nie tot hierdie denkbeeld nie. Beide denkbeelde lê o.a. die onselfgenoegsaamheid van die denke en van die kosmos respektiewelik bloot. Op 'n begronding van my beslissing kan ek hier nie ingaan nie. Maar wie se beslissings is reg of is altwee verkeerd?

Ten slotte wil ek aan Taljaard vra: Waarom tog moet die sedelike nét as funksie36) gesien word? Waarom stem hy nie met Vollenhoven en my saam dat nét die eerste en groot liefdesgebod die religieuse (resp. die gods- 
diens-) wet is nie? Waarom opereer hy met die kosmologiese sentrumfunksie-denkbeeld?

Graag sou ek sien dat teoloë (veral ook in ons land) deelneem aan ons wysgerige gesprekke wat handel oor vraagstukke wat op die grensgebied van teologie en wysbegeerte lê; reeds in Koers, Okt. '47 (bl. 51) het ek hierdie wens uitgespreek. Ons wysgere het hulle nodig.37) H. G. STOKER.

1. Isagogé Philosophiae, 1941, bll. 66, 67.

2. A New Critique of Thzoretical Thought, Vol. 11, p. 147 and 152; Amsterdam 1955.

3. $\mathrm{Vgl}$. my Grond van die sedelike, bll. 28 en 59.

4. Dooyeweerd onderskei nou vyftien wetskringe.

5. Opsetlik spreek ek van, self- en naaste-trou' en nie van, persoonstrou' nie, omdat ek nie weet wat presies Opsetlik spreek ek van, self- en naaste-trou'

6. Die konvers van ,.die sedelike is in die mens-tot-mensverhouding gelee", nl. „die mens-tot-mens-verhouding is in die sedelike geleë", verwerp ons algar omdat daar ook ander as net sedelike verhoudings tussen mense bestaan.

6a. Hierdie bepaling skyn nie heeltemal vir Vollenhoven te geld nie, soos later sal blyk maar wel vir Dooyeweerd en Taljaard.

6b. Taljaard se verduideliking van ,funksie' op bl, 396 as 'n ,vermoë' is enigsins verwarrend Waar al veertien (resp. vyftien) wetskringe-vanaf getal en ruimte tot en met die sedelike en die godsdienstige geloof-
as funksies of funksioneel 7) gesien word moct funksie iets beteken wat aan alle wetskringe gemeenskaplik is 8). Getal, ruimte en trou kan moeilik as, vermoëns' opgevat word, terwyl liefde tot God en jou naaste as 'n van God aan die mens gegewe, vermoe' beskou kan word. Van funksies onderskei die Wysbegeerte van die Wetsidee aktes , which as such cannot be enclosed in a modal (d.w.s. funksionele, H.G.S.) aspec of reality"; - hiervan noem Dooyeweerd as voorbeelde: „perception, representation, remembrance,

7. W.O. sinfunksic of funksionele grondsin, funksionele sinstruktuur, funksionele kringwette, retrosiperende en antisiperende funksies, subjek- en objekfunksies, leidende (resp. bestemmende) en funderende funksies, restriktiewe en ekspansiewe asook verdiepte funksies, grensfunksies, ens.

8. Nieteenstaande die modale verskille van die wetskringe en die daarmee gegewe verskille van die modale funksies self.

9. Isagogé, bl, 53, B.Opm.

10. Isagogé, bll. 53/54, B. 2 en C. 1 .

11. Isagogé, bl. $89 \mathrm{C}$. 1. Soos reeds vermeld sien Vollenhoven slegs die eerste liefdesgebod as religieus maar sover ek nagegaan hel, noem hy dit nêrens die sentrale (religieuse) wet nie; hy noem dit egter we (en volkome skriftuurlik), het eerste en groote gebod' (bl. 67).

12. 'n Mooi (ek mag wel sẻ 'n prototipiese) voorbeeld hiervan is die Kuupernikaanse omwenteling by Kant en die hiermee gegewe teoretiese rede (met sy aanskouingsvorme, kategorieë en idee as funksies), die
praktiese rede (met sy wilsfunksie) en die ,Urteilskraft' (met sy estetiese en teleologiese oordeelsfunksies).

13. A New Critique ..... Vol. I, bl. 5 .

14. "Meaning" of , sin"= die syn of synswyse van die kreatuurlik synde

15. A new Critique..... Vol. I, bl. 11; ck kursiveer.

16. A new Critique ...... Vol. 1., bl. 60. 17. A new Critique
begeerte van die Wetsidee, M. A. verhandeling, b. A. 15 . Kock: Betekenis en plek van die hart in die Wys-

17a. Onder kosmos verstaan ek die ,aardse" skepping.

17b. The modal aspects of our experience are at the same time the modal aspects of all reality in its integro empirical sense. (A new Critique, I bl. 18).

17c. Ek beweer dus ook nie dat die term ,funksie' onbruikbaar is nie; vir sommige beperkte probleemkomplekse mag die denkbeeld sentrum-funksie goeie diens kan doen.

18. Ek spits die weergawe van my denkbeeld net toe op die onderhawige geskilpunte. Daarom noem ek ek nie (wat die Wysbegeerte van die Wetsidee ook aanvaar) bv. die fundamentele beginsels van sondevalverlossing en wêreld-afval-herskepping, die Goddelike wetsorde, ens. nie. Op my leerstuk van kosmiese dimensies (modaliteite, individuele en sosiale strukture, gebeurtenisse (w.o. tyd) en waardes) kan ek

19. Isagogé, bll. 67, e.v. 
20. Isagogé, bl. 22

21. A new Critique. I, bl. 57 .

2:. A new Crltique, I, bl. 60: „An indivisible unity".

23. A new Critique, 11, 149 en 153.

24. Isagogé, bl. 66

25. Dooyeweerd: A new Critique, I, bl. 60.

26. Eksegete moet maar sê of ek reg is. Vollenhoven sien dit ook so, Isagoge, bl. 66.

27. Ook die ander kultuurnorme as die sedelike staan in religieuse verband. Dat die dubbel liefdesgebod net die sedelike noem staan i.v.m. die vraag aan Christus gestel asook in verband daarmee dat belde tot mekaar as beelddraers yan God.

28. Vgl. my Grond van die sedelike, bll. 28 en 59. Ek wil hier net hyvoeg dat àl die skriftuurlike waarhed wat Taljaard i.v.m. sy uiteensetting van, religie' en i.v.m. sy kritiek op verkeerde opvattınge van, religie bied, ook hul aangewese plekke in die denkbeeld vind warmee ek opereer.

29. Die bron van uitgange hoef nie juis 'n sentrum te wees nie; dit kan ook (soos die bron van 'n rivier) hoog of (soos die wortels van ' $n$ boom) laag wees: maar geen van die ruimtelike beelde bevredig nle. Vollen(son Taljaard, bl, 302) nie, maar as religieuse rigtings na God toe of van God weg.

30. A new Critique, I, bl. s,

31. Nie alleen het ek van Dooyeweerd en Vollenhoven geleer nie, maar ook van Bavinck en Hepp. Al word $\mathrm{m} . \mathrm{i}$. tereg ernstige bedenkinge tcen verskillende wysgerige insigte van Bavinck en Hepp geopper,
meen ek tog dat aan die bydraes van Bavinck en Hepp tot ons Calvinistiese Wysbegeerte veel meer betekenis toekom as wat vandag in ons kring erken word.

32. A new Critique, 1, bl. 544.

33. Transcendental Problems of Philosophic Thought, bl. 25.

34. Al gee Dooyeweerd voorrang aan die transsendentale metode, kan ook hy nie sonder die fanero-kritiese metode uitkom nie. Sy insig in die, naiewe ervaring' waarop hy hom telkens beroep, asook sy beroep op skrifwarhede is nie resultate van sy transsendentale mar van die fanerotiese metode bowendien gebruik hy m.i. nolens volens die fenomengese metode (,in U lig) met sy onderske ding van die 'sinskerne' asook van die sumehang van die wetskringe.

35. Ons moet onthou dat meer lyne of denkbeelde as die van sentrum-funksie deur die Wysbegeerte van die Wetsidee loop. Afgesien van die bepaling dat die wetskringe funksioneel is en van hul verband met die hart van die mens as subjektiewe sentrum of met Christus na sy menslike natuur as konsentrasiepun van die hele kosmos, vertoon die wetskring leer met sy rangorde en die hierop geboude leer van individualiteitstrukture. 'n bouplan wat in verskillende opsigie behou kan bly, ook al word die sentrum-funksie. denkbeeld prysgegee.

36. By wat hieroor gesê is en met verwysing na voetnote $6 \mathrm{~b}$ en 29 wil ek die vraag stel waarom trou of ontrou van die kant van die mens teenoor Good nie as 'n funksionele bepaling van, religie' gesien kan word nie. van die kan Taljaard op bl. 309 oor die soendood van Christus sê wil ek verwys na I. Johannes 3 vss. 9 en 14. Die term altrujsme' pas hier nie. Ons mag die menslike natuur van Christus nie van sy Goddelike natur skei nie ook al is Christus as mens Verlossingsmiddelaar; as God is Hy Skeppings- en Her skeppingsmiddelaar. In geen van die gevalle is Hy 'n kosmiese Konsentrasiepunt, 'n Sentrum binne in die skepping nie.

37. Wysgerig teoretiese konstruksies op die grensgehied van teologie en wysbegeerte raak die trologie self Dit is in die teoloë hul eie belang om nie afsydig te staan van die Calvinistıes wysgerige denke nie. Is bv. ons betrokke opvattings van godsdiens en religie. is Dooyeweerd se Christologie (insover die denkbeeld van sentrum-flunksle dit bepaul) en is my het vir verskillende beslissings op sy gebied ook die hulp van die wysbegeerte nodig. 